Journal of Philosophy and Culture, Vol. 3, No. 2 June 2006

\title{
THE ELEPHANT IN PRE-COLONIAL GHANA: CULTURAL AND ECONOMIC USE VALUES.
}

\author{
Kwame Osei Kwarteng \\ Department of History, University of Cape Coast, Ghana
}

\begin{abstract}
Using multi-sources: archeaology, history, geography, anthropology, wildlife, zoology, biology, oral tradition and archival material, the article examines the history of the elephant in Ghana, highlighting the various methods employed in hunting as well as the cultural and economic use values of the elephant in Ghana.
\end{abstract}

\section{Introduction}

Ghana is one of the countries in Africa classified by the IUCN $^{1}$ as elephant range country. In 2002 the Ghana Wildlife Division estimated the country's elephant population at between 1000 and 2000 in eleven separate ranges. ${ }^{2}$ In this article an attempt will be made to establish that elephant hunting in Ghana predated the introduction of guns by Europeans. The economic and cultural significance of the elephant to the people of Ghana will be discussed.

Geographically, pre-colonial Ghana had a large expanse of wilderness of uniformly thick forest and savannah vegetation relieved in only a few places by clearings for settlements and farms. ${ }^{3}$ All over the country game (including elephant) was abundant in the forest, the savannahs and in the coastal bush and grassland. ${ }^{4}$ Although we do not know the exact number of elephants at the time, both forest and savannah zones supported large elephant populations, with Dickson, for example, noting that 'elephants were ubiquitous but tended to 


\section{Kwame Osei Kwarteng}

congregate in thinly populated areas. ${ }^{, 5}$ He adds: 'the coastal lands between Accra and Dixcove had relatively few elephants because of the long period of settlement there.... ${ }^{\mathbf{6}}$ Cardinall corroborates this by observing that in books written two hundred years ago we read them [elephants] having been seen and killed within sight of the very sea itself'?

Both Rattray and Posnasky also allude to the abundance of elephants in parts of Ghana. Rattray refers to Kumawu oral tradition which states that the Kumawu captured and annexed the Afram Plains "which was full of elephants from Fweafo, who were its original inhabitants." ${ }^{, 8}$ For his part, Posnasky notes that the area immediately to the south of the bend of the Black Volta 'probably [had] abundant game..., and elephants to provide ivory'. 'Similarly, Bowdich writes that '... elephants are remarkably numerous in Kong...but they are also found in Ashantee....10 These seemingly plentiful elephants were subject to intense hunting by professional elephant hunters.

\section{Elephant Hunting From The Earliest Times}

The mainstay of Ghana's economy since the late nineteenth century when cocoa was introduced has been cash crop agriculture. However, according to Nketia, before the advent of the cash crop economy, not only was hunting the most important profession in Ghana, it also required bravery and a thorough knowledge of the forest. ${ }^{11}$ Nketia categorises hunters into assistant hunters and master hunters. The distinction between the two was based on the type of animal hunted. Assistant hunters killed only small animals, while master hunters killed dangerous animals like elephants and buffaloes. Master hunters were also ranked according to their exploits, chiefly the number of elephants that they killed during 


\section{The Elephant in Pre-Colonial Ghana}

their career. Accordingly, there were three distinct ranks of master hunter: the lowest on the rung were hunters who had killed only one elephant; occupying an intermediate rank were those who had killed two elephants; while those who killed three or more elephants in their career as hunters were ranked highest. ${ }^{12}$

What were the likely origins of hunting in Ghana? Evidence gleaned from archaeology, and corroborated by oral tradition, provides some answers. According to Anquandah, recent archaeological studies carried out in the woodland savannah and forest belts of Ghana have revealed that from about 10,000 B.C. onward, Late Stone Age hunter-gatherers who fashioned microlithic and flake industries occupied the savannah and forest, and set up intensive food gathering, fishing and hunting economies. ${ }^{13}$ Turning to traditions of the Akan (the Asante), Rattray 'actually record[s] an era when game, fish, wild herbs, berries and roots were the sole food of the people. ${ }^{14}$ It would appear, therefore, that hunting commenced during the Late Stone Age when people who were hunters of animals and gatherers of wild food and fruits infiltrated the woodland savannah and forest zones, ostensibly from the Sahel and Sudan savannah belts, and began to eke out a living in these vast wildernesses at their disposal.

The archaeological evidence suggests further that Early and Later Stone Age populations were culturally adapted to their specific ecological zones. For example, a microlithic population represented at Gao lagoon in the Accra plains combined hunting with exploitation of shellfish and other fish resources in the local lagoon and river environment. On the other hand, the populations of the savannah zone of Ghana had a strong microlithic tradition which exploited the animal 


\section{Kwame Osei Kwarteng}

resources of that ecological belt. However, in the forest zone, opportunities for hunting were minimal, with people specialising in grubbing up wild tubers and roots using stone picks and hoes.

The hunter-gatherer populations made a transition from the microlithic tradition to the Neolithic culture and developed sedentary habitation and farming. People began to cultivate land to produce food and also to domesticate some of the wild animals. There is a suggestion that food production and domestication of animals started in, and diffused outward from, Kintampo and Mumute in Brong Ahafo Region and Ntereso in northern Ghana. ${ }^{16}$ The transition to food production and animal rearing did not result in a sudden break with the past. The new rudimentary form of food cultivation existed side by side with the established occupations of hunting and food gathering, and for centuries was subordinate to them. ${ }^{17}$

Closely related to the genesis of hunting was the type of animal early hunters killed with the technology at their disposal. Did they hunt only small animals or did their kill include big game such as elephant? It appears unlikely that Stone Age Men equipped with rudimentary stone implements were capable of killing elephant or any big game. At best, stone implements could be used to hunt small game, a view which appears to be shared by Dickson, who notes that in his attempt to wrest a living from the physical milieu that surrounded him in Ghana, early man may have collected food and hunted, wherever possible, small animal. ${ }^{18}$

However, according to Anquandah, faunal evidence of elephants, hippopotami, carnivores, antelopes, duikers and catfish remains have been found in excavations at Ntereso and Kintampo, where hunting and fishing played a part in the 


\section{The Elephant in Pre-Colonial Ghana}

subsistence economy of early pastoralists. The discoveries also included stone implements such as the bifacially-flaked stone arrowheads and bone harpoons and fish hooks of Ntereso, and the polished stone arrowheads of Boyase Hill. ${ }^{19}$ Such archaeological evidence suggests strongly that big game hunting, including elephant hunting, did not start after Europeans introduced firearms into Ghana. It started when settled agricultural and pastoral livelihoods emerged in the woodland savannah during the Neolithic stage of man's cultural evolution, with the cradle of elephant hunting being in Ntereso in the Savannah and Kintampo in the transitional zone.

Elephant hunters continued to use stone tools until they acquired iron technology, following which more sophisticated iron implements such as spears and arrows tipped with iron heads, knives and axes were manufactured. Though iron tools existed alongside stone tools for a long time, the possession of iron implements seemed to have given a boost to the hunting of big game, particularly elephants, which required great skill and sophisticated iron weapons or implements. ${ }^{20}$

Archaeological evidence dates the iron workings of Hani (Begho) in the Brong Ahafo Region to the Second Century A.D. Other iron working sites in the woodland savannah and Brong Ahafo were Abam in Bono Manso, Bonoso in Wenchi, Dapaa in Begho, and New Buipe in Gonja in northern Ghana. On the Accra plains the iron working sites were found at Gao lagoon and Cherekecherete; and in the forest area at the following Adanse towns: Dompoase, Akrofrom, Bodwesanwo, Akrokerri, Edubiase and Adanse Odumase. The rest of the iron working sites were Abodum, Domiabra, Kokobin and Manso all in Akyem Kotoku area. Between A.D.1000 and 1500, many of these iron- extractive 


\section{Kwame Osei Kwarteng}

industries were established and were smelting iron and manufacturing iron implements before firearms were introduced into Ghana by Europeans. ${ }^{21}$

What were the hunting methods employed by the ancient hunters? This may be inferred by examining the various hunting methods known to have been employed in various African cultures which were contemporaneous with the period we are considering. Van Couvering identifies some hunting tactics employed by modern African hunters which were also used by ancient hunters as mob attacks with spears; pitfalls; burning of game-rich bush; and hamstringing. ${ }^{22}$

It is reasonable to suppose that of these techniques, the ancient elephant hunters in Ghana during the Late Stone Age used either bush burning or hamstringing, although Van Couvering admits that the latter "entailed a high risk on the part of a hunter equipped only with a stone axe or knife'. ${ }^{23}$ Use of other methods like mob attacks with spear and pitfalls were apparently adopted during the Iron Age. As the spear is an iron implement, there is little doubt that hunters began to use it as a hunting tool after adopting iron technology.

With regard to the pitfall method, it is safe to assume that a pit meant to trap an animal the size of an elephant could only be dug with iron implements (axe, hoe and cutlass) rather than crude stone tools. Thus, it would be reasonable to assume that during the Iron Age, hunters, particularly those in the forest belt in the south, used the pitfall technique in hunting elephants. Indeed Asante tradition recorded by Asare, ${ }^{24}$ and quoted by McCaskie, states that:

Halting at the camp of Atia Boro, a hunter, Osei Tutu and his men asked for meat. They are informed that an elephant (esono) has been trapped in a pit but is 


\section{The Elephant in Pre-Colonial Ghana}

immovable. Osei Tutu removes the elephant's carcass from the pit....

Clearly, the elephant did not fall into the pit accidentally; the pit would have been dug by Atia Boro, the hunter, for the sole purpose of entrapping elephant and perhaps other big game. This method of hunting may have existed alongside the use of guns and gun powder in seventeenth and eighteenth centuries, but it appears that it was very popular in the forest belt during the Iron Age. During the Iron Age both the Akan in the forest belt and savannah groups like the Gonja and Mole-Dagbani used bows and arrows, spears, and javelins as traditional weapons for war as well as for hunting purposes. ${ }^{\mathbf{2 6}}$ However, from the 1650s, European trading companies introduced firearms into the Gold Coast, ${ }^{27}$ with the result that arms proliferated in the coastal and forest regions and were used for military and hunting purposes. The adoption of muzzle-loading guns to hunt elephant and other game led to the emergence of two distinct elephant hunting methods in the country. Coastal groups, along with the Akan who lived in the forest belt (Asante, Assin, Denkyira, Kwahu, Akwamu, Akyem, etc), where European goods circulated freely, bought these guns and used them, both for defensive and offensive purposes, and for hunting elephants and other animals. At the same time, savannah inhabitants continued to use their traditional bows, arrows and spears for elephant hunting.

Arhin indicates that arms and ammunition became available in the northern markets after 1874, when Asante authority over her hinterland was undermined by the British invasion of Kumasi. ${ }^{28}$ It appears that long after Asante had stopped restricting movement of arms and ammunition to the 


\section{Kwame Osei Kwarteng}

north, savannah elephant hunters continued to use bows, arrows and spears. This is borne out by Cardinall, a former District Commissioner of Northern Territories and Western Ashanti who notes in In Ashanti and Beyond that the north had practically no guns in the early twentieth century, and that elephants were killed with bows, arrows and spears. ${ }^{29}$

There is reason to believe, too, that both the Ntereso and Kintampo areas have a long tradition of hunting and history of large elephant populations. Indeed elephant hunting here, which started in pre-historic times, appears to have persisted into the twentieth century. In the case of Kintampo, hunting traditions recorded by Sekyi-Baidoo indicate that local towns and villages, and adjacent districts in the northern part of Brong Ahafo Region, particularly towns like Kunso, Dromankese, Krabonso, Tanoboase, Tuobodom, Nchiraa and Droboso, were noted for elephant hunting until the disappearance of elephants from these areas. ${ }^{30}$ Tradtions related by Nana Kwabena Bofuo, a renowned elephant hunter and the Chief Hunter of Kunso ${ }^{31}$ and Nana Kwame Ntem, a hunter and Atufuohene of Abease traditional area, ${ }^{32}$ confirm the abundance of elephants in the the Nkoranza, Kintampo and adjoining districts up to the Afram plains. Nana Kwabena Bufuo, however, indicates that today probably because of the construction of the Akosombo dam, the elephants no more come around. ${ }^{33}$

There is no evidence to suggest that the people who occupied the Kintampo area in the twentieth century were the direct descendants of the early hunter-gatherer population which lived there in pre-historic times. However, there is a suggestion that elephant hunting in the Kintampo area persisted 


\section{The Elephant in Pre-Colonial Ghana}

as a profession up to the twentieth century because of the abundance of elephants in the area.

With respect to Ntereso in northern Ghana, there is evidence which suggests that the area's long tradition and history of elephant hunting was due to the area's rich elephant resources which might date to antiquity. Daaku writes, for instance, that Gonja and Dagomba in northern Ghana were major sources of Asante ivory supplies in pre-colonial times, ${ }^{\mathbf{3 4}}$ notably when the two areas were under the hegemony of Asante. Also, during the colonial era, elephant hunting was prevalent in the north, particularly in Gonja district. For instance, in 1924 the Chief Commissioner of the Northern Territory in a report referred to the invasion of then Bole District by Asante hunters, ${ }^{35}$ providing confirmation that elephant hunting was still taking place in the first half of the twentieth century in Ntereso.

\section{Rites Associated with Elephant Hunting Among the Akan.}

McCaskie notes that 'the elephant was both unpredictably dangerous-spiritually as well as physically-and the largest single source of animal food in Asante forest. ${ }^{, 36}$ This made elephant hunting a perilous venture. The Akan of Ghana have the intrinsic belief that just like mankind, some animals, including the elephant, have spirits which survived the death of the animal. Rattray, ${ }^{37}$ Nketia, ${ }^{38}$ and Sekyi-Baidoo ${ }^{39}$ state that hunters classified wild animals into two: those with spirit (sasammoa) and those without (mmoa). The former were deemed to have malevolent spirits which lived on after the animal had been killed by a hunter, and which could haunt its killer and cause calamity to befall him during subsequent hunting expeditions. Sasamoa include bongo, elephant, roan, 


\section{Kwame Osei Kwarteng}

waterbuck, duyker, black duyker, yellow-black duyker and antelope. Sekyi-Baidoo points out that, uniquely among these animals, the killing of the elephant reportedly brought honour to the hunter; for this reason, and in spite of the inherent risks, some hunters targeted the elephant, while others avoided it. ${ }^{40}$ Clearly, the elephant enjoyed special status among animals with spirit (sasammoa), because it was considered as the king of the jungle. This is illustrated by Akan proverbs such as 'osono akyiri nni aboa' ( there is no wild animal besides elephant), 'wodi ssono akyiri a hasuo nka wo' (if you follow the trail of elephant you would not be drenched by dew'etc.)

Nketia has documented the necessary ritual preparations which fortified elephant hunters spiritually before they embarked on hunting expeditions. This process of fortification involved undergoing a ritual bath. ${ }^{41}$ In the case of hunters celebrating their first elephant kill, a second ritual called $a b \supset f u o,{ }^{42}$ 'elephant funeral', was performed to appease the spirit of the animal. ${ }^{43}$ For experienced hunters, abəfuo was not performed after every kill, since it was assumed that they possessed sufficient spiritual endowment to render them immune to any threat or danger posed by elephant spirits. ${ }^{44}$

Sekyi-Baidoo has recorded the rituals Kunso elephant hunters performed after killing an elephant, and is worth quoting here:

As soon as the elephant falls, the hunter prepares some 'medicine' out of black pepper and the bark and roots of trees and plants which are found on the spot the animal fell. This is used to stuff the animal's anus and nose in order to prevent its spirit from escaping through these outlets. After this, the hunter cuts bits of the trunk of the animal, its ears, tusks, tail and then covers the eyes and its ears. The cutting of trunk ear 


\section{The Elephant in Pre-Colonial Ghana}

[sic] and the closing of the eyes is to prevent the spirit from exercising its senses of smell, hearing and sight. After this, the hunter comes home with the tail of the elephant. As he approaches home, he and his attendants chant victory songs (which are recitatives) to announce to the village a successful elephant-hunt. ${ }^{\mathbf{4 5}}$

However, this account seems to be slightly different from what was obtained in Ahafo and from the account contained in Nketia. An informant recounted that in Ahafo, "when an elephant was killed, the hunter who killed it cut the tail and the tusk and then proceeded home with them as exhibits to inform the chief and the people that he had killed an elephant. ${ }^{46}$ Nketia states that a hunter who killed an elephant plucked a leaf and put it in his mouth and then went home to report the killing, after which he would undergo the necessary ritual bath, which made him acquire physical and spiritual power over animals. ${ }^{47}$

He suggests that the rationale behind the elaborate ritual was that a hunter was assumed to have died and been resurrected after killing a dangerous animal like an elephant. The occasion was thus both joyous and sobering. The king of all animals, which was thought to have a spirit like a human being, had been killed and this was equated to homicide. Thus while celebrating the elephant kill, cleansing rites needed to be performed to prevent the spirit of the elephant from haunting the hunters. ${ }^{48}$ In Kunso, these 'elephant funeral' rites commenced at $8.00 \mathrm{pm}$, and entailed the pouring of libation by the chief hunter to invoke the spirit of dead hunters for their permission and protection against any unforeseen events, which was followed by the singing of hunting songs, drumming and dancing. ${ }^{49}$ Failure to appease the spirit of the 


\section{Kwame Osei Kwarteng}

dead elephant could result in one or another of the following disasters striking the hunter: 'he would never again be able to kill an elephant; he would grow immensely fat and die; he would always want to sleep; he would eat all day and never be satisfied.' Rattray explains that these disasters would be caused by the sasa, the spirit of the elephant. ${ }^{\mathbf{5 0}}$

While elephant hunting was undoubtedly a hazardous venture, the importance of the elephant and its products in the performance of important social, cultural and economic functions in society meant that hunters risked their lives to hunt the pachyderm.

\section{Cultural Use Values Of The Elephant}

An examination of the available evidence shows that the pachyderm has had both cultural and economic uses in Ghana since time immemorial. The African continent is known for its varied cultures, with wildlife playing a prominent role in almost all its cultures. Wild animals or materials associated with wildlife are used as paraphernalia of traditional African rulers. The elephant, which Nketia describes as 'the king of all animals', ${ }^{\mathbf{5 1}}$ featured prominently as both cultural material and symbol (totem) in Ghana. According to Marc Parren the elephant is one of the most important symbols of state. It stood for strength and power. ${ }^{52}$ Thus the Zulu of South Africa address their king as 'Great Elephant',or 'Powerful Elephant ${ }^{\mathbf{5 3}}$

Apart from its use as a totem for kingship, the elephant has been seen as the abode of ancestral spirits. Olindo observes that:

For the African people, the elephant has been a prominent part of their continent from time immemorial. Africans have either regarded elephants as the host of their ancestral spirit- 


\section{The Elephant in Pre-Colonial Ghana}

which makes the elephant a sacred animal to such communities. Some African communities, greatly fearing for their safety and well being, have migrated widely over the centuries to avoid elephants. ${ }^{54}$

He further notes that the Abaluhya people of Kenya believed that the souls of their brave warriors reposed in elephants. Therefore, Abaluhya people would neither hunt the elephant nor eat its meat. When an elephant died a natural death, the people would collect the ivory and send it to their chief for use as ornament. ${ }^{55}$

These beliefs have parallels in Ghana, where the association of the elephant with chieftaincy is common. Generally, the traditional stools of Ghana have wildlife as their symbol; every stool or skin has its totem which is either a bird or an animal or a reptile. Here, the emphasis will be on kings and chiefs who used elephant as their stool symbols. In the Greater Accra Region, the people of Old Ningo, ${ }^{\mathbf{5 6}}$ Osudoku and Shai $^{57}$ traditional areas have adopted the elephant as their totem. According to tradition of the Shai recorded by Okyeame Ampadu-Agyei, the people took the elephant as their totem because 'an elephant directed their ancestors to a river when they were thirsty in the course of a war.' For this reason, an annual festival known as Pamyam was instituted in honour of the totem. ${ }^{58}$ The Old Ningo and the Osudoku also adopted the elephant as their totem because of its benevolence to their ancestors in the past. Okyeame Ampadu-Agyei writes that Old Ningo tradition asserts that an elephant 'carried one of their ancestors to safety when he was abandoned after a war. The man fell asleep on the back [of] the elephant and the animal took him to a river. ${ }^{59}$ Osudoku tradition also holds that an 


\section{Kwame Osei Kwarteng}

elephant cleared the way for the ancestors during their migration to settle at their present abode. ${ }^{60}$

In the Central region the paramount chiefs of Denkyira, Eguafo, Abura, Ajumako and Abeaze have elephants as their stool symbol. ${ }^{61}$ Denkyira was once a powerful state in the forest belt which, until 1701, was the super power in the forest belt; its subjects included Asante, Wassa, Sehwi, Twifo, Aowin and Adanse. Not surprisingly, Denkyira adopted the powerful elephant, 'the king of all animals', as its totem. Indeed, the first stool (throne) of Denkyira, which was lost when the Denkyira army was crossing the Pra River after a war with the Twifo in the seventeenth century, was made of ivory. ${ }^{62}$

For their part, the Eguafo associated themselves with the elephant because, just like the Denkyira, they saw the elephant as the king of the forest. According to tradition, the first chief of Eguafo, Nana Kwamina Ansa I, rode an elephant. As regards the Abura traditional area, they adopted the elephant as their totem because as great warriors they equated their strength to that of the elephant. ${ }^{63}$ The Ajumako have the elephant and Bushbuck as the emblem of their paramount stool because both animals were common in the area. But, unlike Eguafo and Denkyira, the Ajumako regarded the bushbuck and not the elephant as the king of the forest. Both the Ajumako and the Abeaze people have instituted the Akwambo and Eguakese festivals, respectively, in honour of their totems. ${ }^{64}$

Other Akan traditional areas which had the elephant as totem are Offinso in Ashanti Region and Wassa Amenfi in Western Region. The ancestors of the Offinso people, according to tradition, originated from the belly of an elephant. For this reason the elephant is the main symbol of the Offinso 


\section{The Elephant in Pre-Colonial Ghana}

stool; the linguist staff or insignia is topped by an elephant. ${ }^{\mathbf{6 5}}$ With respect to Wassa Amenfi, the adoption of the elephant as a totem was based on the Akan proverb that 'when an elephant steps on a trap it fails to spring back', which is taken to signify the ultimate authority of the paramount chief as the preeminent person in the Amenfi traditional area. Just like Offinso, the linguist staff of the traditional area has the elephant displayed on it. ${ }^{\mathbf{6}}$

In the savannah region the skins of Kayoro traditional area in Upper East Region and the Mamprusi and Yinyuo traditional areas in Northern Region have the elephant as their totem. Though the Kayoro skin has twelve totems, the elephant was the most important of these. In both the Mamprusi and Yinyuo traditional areas, where the elephant was the symbol of authority, the Damba festival was celebrated annually in honour of the totem. ${ }^{67}$

Apart from the use of the elephant as symbol by some traditional authorities in Ghana, the by-products of the elephant have been utilized as raw material for royal regalia and cultural artefacts. Ross, ${ }^{68}$ Wilks $^{69}$, McCaskie, ${ }^{70}$ Kyerematen $^{71}$ and Rattray ${ }^{72}$ have provided accounts of the various uses to which the Asante have put elephant products. Valerie Sackey also makes a terse reference to the cultural uses of the products of the elephant in Ghana by oberving that 'every major chief has an orchestra of horns made from hollow tusks. The tail with a decorated and sometimes gold encrusted handle, is carried by messengers. The ears are used for special drums, whilsts pieces of skin are used as mats on which the chief's stool (throne) or an important shrine is placed. ${ }^{\mathbf{7 3}}$

First and foremost, the most important symbol of the Asante Kingdom, the Golden Stool (Sika Dwa), which 


\section{Kwame Osei Kwarteng}

represented the soul and spirit of the Asante nation, was never allowed to touch the ground. During important festivals like Odwira and Adaekese, Hwedomtea, the chair upon which the stool was displayed, was placed on the hide of an elephant ${ }^{74}$ (banwoma), which served as a carpet. ${ }^{75}$ Similarly, the blackened stools of the paramount chiefs (Amanhene), ${ }^{76}$ and even some powerful and famous shrines, ${ }^{77}$ were also placed on banwoma. It was for this reason that in the past, it was mandatory for elephant hunters to present the hide of the elephant to the paramount chief of their state or kingdom. ${ }^{78}$ In addition, Rattray records that the hide of the ear of the female elephant was used to manufacture the atumpan, a pair of talking drums, for the chiefs of Asante. ${ }^{79}$ The use of elephant hide in the carving and manufacture of these drums made it the abode of the spirit of the elephant. Before using these drums the drummer invoked the spirits of the various materials, which were used in making the composite drum, propitiated them, and then called upon them to dwell in the drums. Accordingly, the drums became the abode of the spirits of forest trees and the 'mighty elephant'. ${ }^{\mathbf{8 0}}$

Not only was the hide of the elephant used as carpet for the stools of the Amanhene, it was also the material for the treasury bag of the Asantehene (Sanaa or foto ) a symbol of the wealth and generosity of the Asantehene. ${ }^{\mathbf{8 1}}$ The elephant was also used by Osei Tutu I, the founder of the Asante nation, to make a crown. Reindorf and McCaskie give varied versions of the tradition which relates how Osei Tutu used elephant hide to make a crown when he was on his way back home from Akwamu to Kwaman to succeed his uncle, Obiri Yeboah, who was killed by the Domaahene Adom Kusi. Reindorf's version 


\section{The Elephant in Pre-Colonial Ghana}

of the tradition related that Osei Tutu picked 'a piece of skin from the elbow of an elephant and the head of a king fisher Osei Tutu worked into a crown on his way to Kumase'. ${ }^{82}$ On the other hand, McCaskie writes that the Asantehene-inwaiting Osei Tutu '...then takes possession of the elephant's tail (mmra), together with its tusks, ears, and the skin of one of the knees. He uses the mmra to adorn his cap. ${ }^{\mathbf{8 3}}$ Though it is not categorically stated that the cap was made from elephant hide, the explanation offered by McCaskie, coupled with the evidence provided by Ross, ${ }^{\mathbf{8 4}}$ clearly leaves us in no doubt that the cap was made of elephant skin as Reindorf's version indicates. McCaskie elucidates:

The cap is still a vital part of the Asante royal regalia. It is placed on the head of the Asantehene-elect during the enstoolment rites, and it is a commemoration and a mnemonic of incidents which occurred on Osei Tutu's heroic journey from Akwamu to Kumasi. ${ }^{85}$

This cap is what Ross quotes Kyerematen as referring to as "headdress worn by the Asantehene during the most solemn part of his installation, when he takes his oath of office while holding the Bosumuru sword in his right hand and the elephant hide shield in his left. ${ }^{\mathbf{8 6}}$

Apart from its use as material for royal regalia, elephant hide played an invaluable role in the puberty rites of Akan girls, according to Rattray. The mouth of the girl undergoing the rites was touched three times with three roasted pieces of an elephant's ear, with each piece being allowed to fall to the ground. ${ }^{87}$ The significance of this ritual was that the girl undergoing the rites was being told to develop a big womb (or elephant womb) for procreation. In other words the ritual was 


\section{Kwame Osei Kwarteng}

meant to make the girl productive as the Akan frown on barrenness.

Another elephant product which had royal significance as paraphernalia in Asante was the tail (mena). Rattray, Bowdich, Wilks and McCaskie, and Ross have either made detailed documentation of, or passing references to, the tail of the elephant in Asante. Wilks, McCaskie and Ross allude to the Golden elephant tail (Sika mena) of the Asantehene. The Asantehene alone had the power to use the elephant tail or whisk with a gold handle, which symbolised the wealth of the Asante nation. ${ }^{\mathbf{8}}$ McCaskie observes that 'the key symbolic artifact deployed by the state was the Sika Mena or Golden Elephant Tail....Each Asantehene, from Osei Tutu onwards created his own Sika Mena. ${ }^{\mathbf{8 9}}$ However, in the nineteenth century, chiefs and individuals who were honoured with the title sberempon by the Asantehene for public exhibition of their accumulation of wealth were given the right to use the elephant-tail switch (mena) as the most coveted of all honours. In the nineteenth century, three chiefs who achieved the honour were Gyaasewahene Opoku Frefre, Ankobeahene Kwaku Tawia, and Mawerehene Kwasi Brantuo. ${ }^{90}$

Besides honouring people who publicly displayed their wealth, the Asantehene honoured priests and shrine attendants with the elephant tail switch for providing spiritual fortification for the occupants of the Golden Stool and members of the Oyoko royal family of Kumasi. According to Mim sbos shrine tradition:

during the reign of Asantehene Kwaku Dua Panin in the nineteenth century, the Mim sbo shrine and its priests were honoured by the Asantehene for providing a number of 


\section{The Elephant in Pre-Colonial Ghana}

important services to the Golden Stool. In the first place the Mim sbo sod helped a female relative of the Asantehene who was barren to produce a child. Secondly, the god was consulted severally by the Asantehene and he got positive answers to his request. And lastly, the Asantehene wanted to find out whether the shrine was truly spiritually powerful as indicated by its popularity. So he tested the Mim دbos, by sending three servants to Mim with three items: the first was concealed gold dust, the second was concealed palm nut and the last was a piece of concealed women's loin cloth. Mim Jbo s shrine was asked to identify the three items. The shrine or god passed the test by identifying the contents. For achieving this feat, the Asantehene honoured the Mim כbo shrine by creating a Chief-Priest for the shrine with a number of royal paraphernalia including elephant-tail (mena) ${ }^{{ }^{11}}$

The elephant tail was carried by young royals, ${ }^{\mathbf{9 2}}$ or servants, usually boys called ahoprafo, who carried it before the rulers to brush away danger or dirt. ${ }^{93}$

Moreover, the mena had judicial function. Informants at Mim and Abease indicated that the Paramount Chiefs summon people who committed offences to the palace just in the same way as a bailiff executed court summons. At Mim, Nana Akwasi Manu stated that 'it was a grievous offence for any subject of the Asantehene or any chief be he Jberempon (wing chief) or Omanhene to refuse the summons of Asantehene executed by a servant carrying mena. ${ }^{94}$ On his part Nana Kwame Ntem asserted that 'the elephant tail was used to summon people who misbehaved or showed disrespect to the Omanhene of Abease to the palace. Anyone who defied such summons was deemed to have committed a serious offence against the stool or the Omanhene. ${ }^{95}$ 


\section{Kwame Osei Kwarteng}

Chiefs used elephant ivory for both ornamental and ceremonial purposes. The ivory horn is associated with Ghanaian chieftaincy. Elephant ivory was the main material used in the production of ivory trumpets used by court officials such as praise singers to eulogise chiefs during special occasions. Rattray identifies three different types of ivory horns used in Asante, to wit, 'nkufe', 'ntahera', and 'asokoben'; ${ }^{\mathbf{9 6}}$ which were blown by court officials called asokwafos. ${ }^{97}$ Kyrermaten corroborates this by noting that the Asantehene's regalia contain a number of ivory horns, many of them named and performed specific roles. ${ }^{\mathbf{9 8}}$

Apart from the Asantehene, the other Amanhene, including the wing chiefs or aberempon, have their own ivory horns and horn blowers. Similarly, every Akan Omanhene also had his horns and horn blowers. In Bono Takyiman for instance, Baffour Asare Twi Brempong, the Adontenhene, stated that besides the Takyimanhene, each divisional or subchief and even Taa Mensah Bosomfor (priest) has his own ivory trumpets blown to praise him. ${ }^{99}$

These trumpets were carved by craftsmen with special skills. Archaeological evidence indicates that ivory industries appeared in Begho area from the beginning of the second millennium A.D. and reached their peak around the fifteenth and sixteenth centuries, when ornate court ivory trumpets were carved. Between the fifteenth and seventeenth century there were ornamental ivory industries in Bono Manso. ${ }^{100}$ The tradition of Bono Manso confirms this. It related that in preAsante times, there were ivory industries in Bono Manso, and the carvers who were mostly servants of the Takyimanhene carved ivory trumpets and other products for the king. ${ }^{101}$ It 


\section{The Elephant in Pre-Colonial Ghana}

could probably be argued that the genesis of court ivory trumpets was Begho and Takyiman, and their use was diffused to other Akan states, particularly Asante, following the conquest of Bono Takyiman by Asante in the second decade of the eighteenth century. This conclusion seems to be corroborated by Boakye-Boaten, ${ }^{\mathbf{1 0 2}}$ who is quoted by Arhin as observing that "through its successful military /political expansion, the state had enriched Asante crafts through the voluntary and forced settlement in Asante of skilled craftsmen from the conquered territories'. ${ }^{\mathbf{1 0 3}}$

Preston refers to the ivory trumpets as talking horns and adds that the abentia (the Twi name for the ivory trumpet) was used in the past for the start of a war. ${ }^{104}$ In the same way, Kyerematen also notes that the Asantehene's ivory trumpets were associated with war. The ntahera for instance, was captured by Osei Tutu during a war, whilst the 'tatwia' was used 'to give a warning to the enemy that total annihilation awaited them if they did not surrender.'

The elephant remains an important symbol in present day Ghanaian politics. During the inaguration of parliament and the president in 1993, 1997 and 2001 the 'mmenson', the ivory trumpet orchestra, heralded the president's entry into the National Chamber. Additionally, between 1957 and 2000, during every Independence Day celebrations on March $6^{\text {th }}$, 'atumpan' drumming preceded the president's speech.

\section{The Economic Significance Of The Elephant}

Besides its cultural use values, the elephant has economic importance. First, it was hunted for its tusk and meat which were of high economic value. Dickson observes that ivory was a highly prized object of trade whilst elephant flesh 


\section{Kwame Osei Kwarteng}

was an abundant source of food. ${ }^{\mathbf{1 0 6}}$ Anquandah also notes that the large elephant population in the forest belt yielded ivory which engendered commercialisation of the products. ${ }^{107}$ The peoples of Gold Coast in medieval times developed commercial ties with the peoples of Western Sudan. Two main caravan trade routes were developed to link the commercial emporium of Western Sudan with the savannah and forest belts of Ghana. ${ }^{108}$ According to Fynn, one of the routes ran northnorth-west from present day Asante through towns like Bonduku and Mandeland, and terminating at the market centre of Timbuktu. The other trade route ran to the north-east, passing through eastern Gonja and Dagomba and across the Niger to Hausaland. ${ }^{109}$

As merchandise, ivory which was obtained from the forest and savannah was sold alongside other commodities such as gold, kola nut and slaves to Mande-Dyula and Hausa traders from Western Sudan and northern Nigeria, respectively. ${ }^{110}$ However, from the fifteenth century, Europeans such as the Portuguese, Dutch, Bradenburgers, Danes and British established commercial contact with the peoples of Gold Coast and built forts and castles along the coast for the purposes of trade. Following this commercial contact with Europeans the focus of trade shifted from the Western Sudan to the coast.

From the fifteenth century to the nineteenth century or even beyond, 'the Gold Coast was important both as a source of ivory and as an entrepot for shipment to Europe. ${ }^{111}$ According to Daaku, most of the ivory sold at the coast came from the woodland fringes of the forest, and Asante, which dominated the trade, obtained its supply from Ahafo and Gyaman in the west as well as Gonja and Dagomba markets in 


\section{The Elephant in Pre-Colonial Ghana}

the north. Additionally, the Afram plain in the east also abounded in ivory which was ferried on the Volta to Accra and the eastern part of the coastal region by the Kwahu. ${ }^{\mathbf{1 1 2}}$

Daaku suggests that the ivory trade was mainly associated with rulers; this was because, by custom, part of the ivory obtained in each state had to be given to the ruler, who used some for ornamental purposes and sold the rest for his upkeep.' He, however, admits that rich merchants participated in the trade, albeit on a limited scale. ${ }^{113}$ Fynn explains that private individuals were not encouraged to indulge in largescale trading activities because of risks involved. ${ }^{114}$ Bowdich lists ivory export tax as one of the sources of Asante revenue; ${ }^{115}$ and, according to Arhin, in the seventeenth and eighteenth centuries Asante financed its numerous wars of expansion and consolidation with diverse revenue sources, including ivory. He elucidates: 'thus much of Ashanti trade with the European forts on the coast was for guns and ammunition for which they exchanged gold slaves and ivory'. ${ }^{116}$ It is obvious from the above that ivory played a significant role in the economy of pre-colonial states of Ghana, particularly Asante, where revenue from the ivory trade with the European merchants on the coast was a vital source of financing the various Asante wars. The elephant then, is central to the political history of Ghana.

Though the ivory trade in Ghana in pre-colonial days was important to the economy, available statistics seem to subsume Ghana's trade under the broader West African ivory trade, thus making it extremely difficult to quantify the ivory obtained from Ghana during the period under consideration. Daaku, Feinberg and Johnson discuss the ivory trade in Ghana and West Africa with statistical illustrations. Daaku writes: 


\section{Kwame Osei Kwarteng}

Though scarce, ivory returns from the Gold Coast are impressive. This is illustrated from the Dutch records, which show that by 1717 they had collected as much as 67,299 pounds of ivory from five of their least-paying possessions in the twelve years between 1705 and 1717. But the main sources of ivory were the Ivory Coast, Benin, Cameroons, and Angola. In many cases, however, ivory from these regions was first sent to the Gold Coast, thus creating the impression that much of the commodity came from this coast....But in fact this had come from elsewhere. ${ }^{117}$

He added that the biggest single haul of ivory from the Gold Coast was in 1706, when the English shipped 334 teeth of twenty-seven pounds each, which was described as unprecedented. ${ }^{\mathbf{1 1 8}}$

Feinberg and Johnson provide comprehensive statistics on ivory exports by the Dutch West India Company in West Africa, and indicate that more than 1,500,000 Dutch pounds of ivory was exported from West Africa between 1699 and $1725 .{ }^{119}$ Though the Dutch West India Company maintained eleven to fifteen forts on the Gold Coast from Axim to Accra, including Elmina, the company's headquarters and entrepot from where all the ivory was exported to Europe, the statistics never specify the quantity of the commodity actually acquired from the Gold Coast. All the ivory obtained by the Dutch from Argium to Angola was lumped together as West African export. ${ }^{120}$ This created the erroneous impression that all the export came from Ghana. Be that as it may, the fact that the people of Gold Coast exchanged ivory obtained from the forest and the savannah belt for European goods like guns and gun powder underscores the economic value of ivory. 


\section{The Elephant in Pre-Colonial Ghana}

However, records of the quantity of ivory exported from the Gold Coast by the various European nations trading in the territory are available for the second half of the nineteenth century. Between 1859 and 1873, the records indicate, the countries that imported ivory from the Gold Coast included Holland, Britain, the United States of America, France and Portugal. In 1859 a total of 14,7071/2 1b were exported from Gold Coast. Of this, $42801 \mathrm{~b}$ was exported to the United Kingdom; $94201 \mathrm{~b}$ were shipped to USA; $3751 \mathrm{~b}$ went to Holland and $6321 / 21 \mathrm{~b}$ were imported by Portugal. However, France, which was one of the countries that traded in ivory with the Gold Coast, did not import any ivory that year from the country.

\section{Conclusion}

This article has tried to show that elephants were found across large parts of the country; and that elephant hunting began during the Stone Age at Ntereso and Kintampo, possibly for subsistence. With time, hunters acquired iron implements such as iron tipped spears, lances, bows and arrows which were more deadly and sharper than the crude stone implements previously used for hunting elephants. In the middle of the seventeenth century, European traders on the coast introduced flintlock guns and gunpowder into Ghana, but its use for hunting was limited to the coastal and forest belts of the country. Populations in the northern savannah belt continued to use the traditional iron implements of bows, arrows and spears.

Elephant hunting was considered a spiritually and physically dangerous venture because of the Akan belief that the elephant possessed a vindictive spirit which survived its death, and could cause havoc to its killer if no proper rituals 


\section{Kwame Osei Kwarteng}

were performed to placate the spirit of the dead elephant. Thus elephant hunters had to fortify themselves spiritually and also had to perform elaborate elephant funeral rites to propitiate and calm the spirit of the elephant.

It has been established that the elephant have both economic and cultural use values. Its meat was a source of food for centuries for forest and savannah people. Later, people realised the economic significance of elephant ivory which became a hot commodity, and gave impetus to the hunting of the animal. The ivory provided revenue for Asante kings to finance their various wars of expansion. Lastly, the elephant is also important in the political culture of Ghana, with the elephant itself and its products featuring prominently in Ghanaian culture. The animal served as a totem for some stools and skins whose occupants and subjects revered it as a sacred animal. The hide, ear, tail and ivory were all important for the manufacture of royal paraphernalia. The possible rationale behind the wide use of elephant parts as material for royal regalia can be inferred from the Akan saying, ssono akyiri nni boa ('the elephant is the mightiest of all animals)'.

\section{References}

1 http://www.iucn.org/theses/ssc/sgs/afes/aed/pdfs/aesr2002.pdf\#na meddest=afreledat,p205.

2 K.B. Dickson, A Historical Geography of Ghana, Cambridge University Press, London, 1969, p57.

3 Ibid, p84.

$4 \quad$ Ibid, p85.

5 Ibid.

6 A.W. Cardinall, In Ashanti and Beyond, Johnson Print Corporation, London, 1971, p167. 


\section{The Elephant in Pre-Colonial Ghana}

7 R.S. Rattray, Ashanti Law and Constitution, Clarendon Press, Oxford, 1923, p218.

8. Merrick Posnasky, 'Aspects of Early West African Trade' in World Archaeology, Vol.5, No.2, Trade. (October, 1973), p155.

9. E.T Bowdich, Mission from Cape Coast Castle to Ashantee, London, Frank Cass, 1966, p327.

10. J.H. Nketia, Abofodwom, Ghana Publishing Corp, Accra, 1973, p1, see also J.H.Nketia, Drumming in Akan communities of Ghana, Nelson, New York, 1963, p75.

11. Nketia Abofodwom, op cit, p1, See also Johann Yaw SekyiBaidoo, A Study of The Cosmological and Aesthetic Features of the Akan Hunters' Song Among the People of Kunso, M.Phil Thesis Submitted to Institute of African Studies, University of Ghana, Legon, 1994, p36.

12. James Anquandah, Rediscovering Ghana's Past , Longman, Essex,1982, p53.

13. Rattray, Ashanti Law and Constitution ,op cit,p218, the exact time Rattray is referring to is not known, but probably he is referring to the period before the introduction of guns into the country in the $17^{\text {th }}$ Century.

14. Ibid, p54.

15. Ibid.

16. Dickson, op. cit, p 35 .

17. Ibid, p33.

18. Anquandah op. cit, $\mathrm{p} 60$.

19. Dickson, op. cit, p34.

20. Ibid, pp67-69.

21. John .A. Van Couvering, 'Proboscineans, Hominids, and Prehistory' in Elephant: The Animal and Its Ivory in African Culture, Ed. Doran H. Ross ,Pear River, Hong Kong, 1992, p75.

22. Ibid.

23. N.V Asare, 'Asante Abasem (Twi Kasamu)' Basel: Basel Mission Archives, 1915, Ms D/20, 4, 5.

24. T. C. McCaskie, 'People and Animals: Constru (ct) ing the Asante Experience', Africa: Journal of the International African Institute, Vol.62, No.2 (1992), p240. 


\section{Kwame Osei Kwarteng}

25. Kwame Arhin, 'The Financing of the Ashanti Expansion (17001820)', Africa Journal of the International African Institute, Vol.37, no.3. (July, 1967) p283.

26. Kwame Yeboah Daaku, Trade and Politics on the Gold Coast 1600-1720, Clarendon Press, Oxford,1970 , p149 see also Arhin, 'the financing...' op cit, p283.

27. Kwame Arhin, 'Aspects of the Ashanti Northern Trade in the Nineteenth Century' in Africa: Journal of the International African Institute, Vol. 40 No. 4(October, 1970), p363.

28. Cardinall, op. cit, p168.

29. Sekyi-Baidoo, op cit, $\mathrm{p} 30$.

30. Interview with Nana Kwabena Bofuo, Chief Elephant Hunter, 80 years old Kunso, 24/01/06.

31. Interview with Nana Kwame Ntem, Atufuohene of Abease

Traditional Area, 90 years, Benim, near Abease, 23/01/06.

32. Nana Kwabena Bofuo, op cit.

33. Daaku, op cit, p27.

34. Public Records and Archives Administration Department(PRAAD), Kumasi, ARG1/1/107, from Chief Commissioner, Northern Province, Tamale to the Chief Commission, Ashanti, Kumasi, $29^{\text {th }}$ January, 1924.

35. McCaskie, State and Society, op. cit, pp43-44.

36. R.S. Rattray, Religion and Art in Ashanti, Oxford University press, Oxford, 1927, p183-184.

37. Nketia, Abofodwom op cit, pp7-9.

38. Sekyi-Baidoo, op cit, p41.

39. Ibid.

40. Nketia, Abofodwom, op cit, p8.

41. Ibid.

42. Rattray, Religion and Art in Ashanti, , op cit, p184-185,See also Ross, Doran H, 'More than Meets the Eye: Elephant Memories Among the Akan' in Elephant: The Animal and Its Ivory in African Culture , Edited Doran H. Ross Hong Kong, Pear River Printing Company, 1992, p 140.

43. Nketia, Abofodwom, op. cit, p8.

44. Sekyi-Baidoo, op cit, p42. 


\section{The Elephant in Pre-Colonial Ghana}

45. Interview with Nana Akwasi Manu, Kontihene of Mim Traditional Area, 80 years, Mim, $16^{\text {th }}$ November, 2005.

46. Nketia, Abofodwom, op cit, pp8-9.

47. Ibid.

48. Sekyi-Baidoo, op cit, pp79-100. For full details on the elephant funeral rites read the above pages.

49. Rattray, Religion and Art in Ashanti, op. cit, p184.

50. Nketia, Abofodwom, op. cit, pp8-9.

51. Marc Parren, P.E, 'Forest elephant (Loxodonta africana cyclotics Matschie) messenger-boy or bulldozer? : The possible impact on the vegetation, with special reference to 41 trees species of Ghana,' Department of Forestry, Wageningen Agricultural University, August 1991. p29. Marc Parren indicates that elephant was seen carved in the sacred golden stool of Akropong Akwapim. It is true the Okuapemhene has sacred stool on which had been carved elephant. But it is doubtful whether it is a golden stool. In Ghana it was the Asantehene who was historically known to have had a sacred golden stool.

52. Ampadu-Agyei, Okyeame, Handbook of totems in Ghana: A Traditional Mechanism for Biodiversity Conservation, Conservation International Ghana, Accra, not dated.

53. Perez Olindo, 'An African Perspective' in Elephant: The Deciding Decade, Key Porter Books, Toronto, 1991, p62.

54. Ibid, p61.

55. Jacob Oti Awere, 'Totemism and Wildlife Conservation: Ghanaians, know your totem' in Daily Graphic, Graphic Communications, Accra, Saturday, 10/09, 2005, p9.

56. Okyeame Ampadu-Agyei, op cit, p23.

57. Ibid, p23.

58. Ibid, p24.

59. Ibid

60. Ibid, pp15-17.

61. Carl Christian Reindorf, The History of the Gold Coast and Asante, 2nd ed. Basel Mission Depot, Basel, 1889, p49.

62. Ibid.

63. Ibid, p16.

64. Ibid, p8. 


\section{Kwame Osei Kwarteng}

65. Ibid, p34, in all Ghanaian culture a chief is approached or spoken to through linguist. The linguist holds a long staff of about one yard long which is his symbol of authority. On top of these staffs are displayed the totem of the traditional area or the lineage of either the linguist or the chief.

66. Ibid, p31.

67. Ross, op. cit, pp 140-146.

68. Ivor Wilks, Forest of Gold : Essay on the Akan and the Kingdom of Asante ,Ohio University Press, Athens,1993, pp139, 140, $141,143,144,146$.

69. McCaskie, T.C, State and society in pre-colonial Asante, Cambridge University Press, Cambridge, 1995, pp, 43, 44,48,60,71, also McCaskie, 'People and animal' op cit, p240.

70. A.A.Y. Kyerematen, Panoply of Asante, Longmans, London, 1964, pp11,12, see also Kyerematen, Durbar : in Honour of His Royal Highness Prince Wales, Program printed in Dwaberem , Manhyia, Kumasi, (21 March), 1977, p8.

71. R.S. Rattray, Ashanti, op.cit, pp94, 99, 111,216, 259.

72. Valerie, Sackey, 'the effects of Appendix I on Ghana's Elephants' in Proceedings of the African Elephant Conference, Johannesburg, 5-7 May, 1997 pp18-21.

73. Rattray, Asante, op cit, p216.

74. Ross op cit, p 140-141.

75. Interview with Osahene Kwaku Koranteng II, Chief of Kunso, 65 years, Kintampo, 23/01/06, see Ross, op cit, p141.

76. Interview with Nana Kwaku Twumasi, the Dwomohene of Bono Manso, 80 years, Bono Manso, 24/01 2006.

77. Osafohene Kwaku Koranteng II op. cit.

78. Rattray, Asante, op cit, p 259, See also Rattray Religion and Art in Ashanti, op cit p6, see also Ross op cit p141.

79. Rattray, Asante, op cit, p265.

80. Kyerematen, 1977, op. cit, p8, see also Ross, op. cit, 141.

81. Reindorf, op .cit, $\mathrm{p} 53$.

82. McCaskie, 'People and Animals' op cit, p240.

83. Ross op cit, p 141. 


\section{The Elephant in Pre-Colonial Ghana}

84. McCaskie, op 'People and Animal" op cit, p241, see also Ross, op cit, 141.

85. Ross op cit, p141, A.A.Y, Kyerematen, Regalia for an Ashanti Durbar, Kwame Nkrumah University of Science and Technology, Accra, 1961, p13.

86. Rattray, Religion and Art, op cit, p73, see also Ross op cit, 143.

87. Wilks, Asante, op cit, p450, McCaskie, State and Society, op cit, p48, Ross op cit, p143.

88. McCaskie, State and Society. Op cit, p47.

89. Wilks, Forest of Gold, op cit, pp140-141, McCaskie, State and Society, op cit, pp, See also McCaskie State and Society, pp44-59, see also Ross op cit p143.

90. Interview with Nana Kwame Ampoma, Ex-Komfohene, of Mim

91. Jbos, Mim, 65 years, $25^{\text {th }}$ January 2006.

92. Rattray, Religion and Art, op cit, p103, Bowdich op cit, p295.

93. M.D. McLeod, The Asante, British Museum Publication, London, $1981, \mathrm{p} 85$.

94. Nana Akwasi Manu, op cit.

95. Nana Kwame Ntem, op cit.

96. Rattray, Asante, op cit, p94.

97. Rattray, Religion and Art, op cit, p114.

98. Kyerematen, Regalia, op cit, 4, 14. See also Ross op cit, p145.

99. Interview with Nana Baffour Asare Twi Brempong, the Adontenhene of Takyiman Traditional Area Takyiman, 24/01/06.

100. Anquandah, op cit, pp92-93.

101. Nana Kwaku Twumasi,op cit,

102. A. Boakye-Boaten , 'Cultural Ecology of Asante, 1702-1945', $\mathrm{PhD}$ Thesis, Department of Geography, University of Ghana, Legon, 1974, pp146-171.

103. Kwame Arhin, 'Trade, Accumulation and the State in Asante in the Nineteenth Century' Africa: Journal of the International African Institute, Vol.60. No.4, 1990, p533.

104. George Nelson, Preston, Twifo-Hemang and the Akan ArtLeadership Complex of Ghana, Columbia University, PhD, 1973, p55, See also Ross, op cit p145. 


\section{Kwame Osei Kwarteng}

105. Kyerematen, Regalia, op cit, p 14, see also Ross, op cit, p 145.

106. Dickson, op.cit. p85.

107. Anquandah, op. cit, p 87.

108. Fynn, op. cit, p5, See also Dickson , op cit, pp42-44,see also Anquandah, op cit, pp92-94, see also Ivor Wilks, ' A medieval trade-route from the Niger to the Gulf of Guinea' in Journal of African History III(1962),pp337-339.

109. Fynn, op. cit, p5.

110. Ibid, Anquandah, op. cit, p94.

111. Feinberg, Harvey. M. and Marion Johnson, 'The West African Ivory Trade during the Eighteenth Century: The '... and Ivory Complex' in The International Journal of African Historical Studies, Vol.15, No.3, (1982), p436.

112. Daku, op. cit, p27.

113. Ibid, See also Feinberg and Johnson, op.cit, p436.

114. Fynn, op.cit, p117. Trading in the past entailed a lot of risks such as kidnapping by hostile people who lived along the trade routes. Besides, highway men attacked traders and took away their goods and money.

115. Bowdich, op. cit, p320.

116. Arhin, 'The financing of the Ashanti Expansion' op. cit, p283.

117. Daaku, op cit, p28.

118. Ibid.

119. Feinberg and Johnson, op cit, p438.

120. Ibid, pp437-8.

121. The National Archives, Kew Gardens, CO 100/15, The Blue Book of Statistics, Gold Coast Imports and Exports,1859,pp168-169. 